Article

\title{
Use of Calcite Mud from Paper Factories in Phosphorus Treatment
}

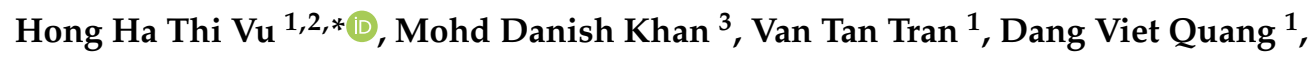 \\ Van-Duong Dao ${ }^{1}{ }^{10}$, Seongho Lee ${ }^{4}$, Ji Whan Ahn ${ }^{4}$ and Seok-ho Jung ${ }^{5}$ \\ 1 Faculty of Biotechnology, Chemistry and Environmental Engineering, Phenikaa University, Hanoi 12116, \\ Vietnam; trantan160288@gmail.com (V.T.T.); quang.dangviet@phenikaa-uni.edu.vn (D.V.Q.); \\ duong.daovan@phenikaa-uni.edu.vn (V.-D.D.) \\ 2 Phenikaa University Nano Institute (PHENA), Phenikaa University, Hanoi 12116, Vietnam \\ 3 Resources Recycling Department, University of Science and Technology, 217, Gajeong-ro, Yuseong-gu, \\ Daejeon 34113, Korea; danish0417@ust.ac.kr \\ 4 Center for Carbon Mineralization, Mineral Resources Research Division, Korea Institute of Geoscience and \\ Mineral Resources (KIGAM), 124 Gwahak-ro, Gajeong-dong, Yuseong-gu, Daejeon 34132, Korea; \\ mujok821@kigam.re.kr (S.L.); ahnjw@kigam.re.kr (J.W.A.) \\ 5 Department of Earth and Environmental Science, Korea University, Seoul 02841, Korea; refresh@korea.ac.kr \\ * Correspondence: ha.vuthihong@phenikaa-uni.edu.vn
}

Received: 12 June 2020; Accepted: 16 July 2020; Published: 24 July 2020

check for updates

\begin{abstract}
To use calcite mud waste generated from the paper production process, calcite mud was treated by calcination and then applied as a sorbent agent to remove phosphorus from an aqueous solution. The pre-treatment muds were characterized by scanning electron microscopy, Fourier transform infrared spectroscopy, and X-ray diffraction. The effects of calcite mud with different calcination temperatures on phosphorus removal were investigated. Different sorbent dosages, contact times, and initial phosphorus concentration conditions were also studied to understand the phosphorus removal mechanism. The results show that phosphorus removal efficiency was increased by increasing the calcination temperature of the mud. The phosphorus removal efficiency over $10 \mathrm{~min}$ increased by $35 \%, 82 \%, 98 \%$, and $100 \%$ with $4.5,6.75,9.0$, and $11.25 \mathrm{mg}$, respectively, of calcite mud calcined at $1000{ }^{\circ} \mathrm{C}$. However, the efficiency decreased as initial phosphorus concentration increased. To study the phosphorus removal trend, the pseudo-first-order, pseudo-second-order, and intraparticle diffusion kinetic models were used. The Langmuir and Freundlich isotherm models were also used to further investigate the phosphorus adsorption mechanism characteristics of the calcite mud.
\end{abstract}

Keywords: calcite mud; calcium oxide; sorption; phosphorus removal

\section{Introduction}

Phosphorous is an essential component in the global chemical industry, including in the production of batteries [1], detergent [2], and pharmaceuticals [3]. However, it is a non-renewable natural mineral resource. The excessive discharge of phosphorous from industrial factories to bodies of water could lead to eutrophication, water pollution, and severe environmental issues [4-10]. Removal of phosphorous pollution from the wastewater of industrial factories is an important issue due to the increasing amount of phosphorous discharged. Several studies were conducted in an effort to develop efficient and economical methods for the removal of phosphorous from wastewater [11-14]. Several approaches were developed, such as biological-based, crystallized, and chemical-based approaches [15-17]. The biological-based approach is known as the traditional approach, but it is not suitable for some kinds of wastewater due to the toxicity to the microorganisms 
within [18]. Hydroxyapatite $\left(\mathrm{Ca}_{10}\left(\mathrm{PO}_{4}\right)_{6}(\mathrm{OH})_{2}\right)[19,20]$ and magnesium ammonium phosphate $\left(\mathrm{MgNH}_{4} \mathrm{PO}_{4}\right)$ [21,22] are two chemicals used in the crystallized approach that can efficiently remove phosphorus in low and medium concentrations. This method can achieve a removal efficiency of up to $95.82 \%$ [19]. The chemical precipitation technique has attracted attention due to its high removal efficiency and simple process [23-25]. Other research using mussel shells to remove phosphorus achieved a high efficiency rate of $99 \%$ [25].

Using waste resources, such as calcite mud, in the removal of phosphorus in aqueous solutions has recently attracted considerable attention. This approach provides high rates of phosphorus removal and enables the possible use of the waste resources from other industries $[25,26]$. Calcite mud is a significant waste resource in the pulp and paper industries. It is discharged in paper production when converting wood chips into pulp. Approximately $0.47 \mathrm{~m}^{3}$ of calcite mud is produced from every ton of pulp [27]. The use of calcite mud is currently limited in the industries, with approximately $30 \%$ of the total calcite mud produced being retained, and almost $70 \%$ of the remaining calcite mud being discharged into the environment. Thus, critical environmental issues can arise without the careful management of calcite mud.

In this paper, we propose an efficient method for the removal of phosphorus in aqueous solutions using the discharged calcite mud. Calcite mud mostly contains calcium in the form of calcium oxide $(\mathrm{CaO})$, calcium carbonate $\left(\mathrm{CaCO}_{3}\right)$, and calcium hydroxide $\left(\mathrm{Ca}(\mathrm{OH})_{2}\right)[28,29]$. Calcium compounds can efficiently remove phosphorus with up to $100 \%$ efficiency through the fabrication of calcium hydroxide nanoparticles with a mass ratio between calcium and phosphorus of over 5.3 [30]. The calcium-based precipitation approach potentially provides high efficiency removal with few adverse effects. For instance, metal ions (e.g., $\mathrm{Al}^{3+}, \mathrm{Fe}^{3+}$ ) and anions (e.g., $\mathrm{SO}_{4}{ }^{2-}, \mathrm{Cl}^{-}$) are not produced in this precipitation approach as they are in methods using other metal salts. In an effort to develop a simple and efficient procedure for using calcite mud, we propose a heat-treatment method to synthesize $\mathrm{CaO}$ from the calcite mud and use it to efficiently precipitate phosphorus in aqueous solutions.

\section{Materials and Methods}

\subsection{Pre-Treatment Calcite $\mathrm{Mud}$}

The calcite mud used in this study was gathered from the Moorim paper factory in city, South Korea. The mud was washed several times with distilled water, followed by drying for $24 \mathrm{~h}$ in an oven at 80 ${ }^{\circ} \mathrm{C}$. The collected dried mud was calcined in a furnace at 800 or $1000^{\circ} \mathrm{C}$ for $1 \mathrm{~h}$ each. The calcined mud samples were kept in sealed bottles to keep them from reacting with the oxygen in the air.

\subsection{Batch Experiments}

The phosphorus removal experiments were conducted using a batch method at room temperature. A stock solution of phosphorus of $60 \mathrm{mg} \mathrm{TP} / \mathrm{L}$ (total phosphorus/liter) concentration was prepared by dissolving potassium dihydrogen orthophosphate salt $\left(\mathrm{KH}_{2} \mathrm{PO}_{4}\right)$ (Daejung Chemicals \& Metal Co., Korea) in distilled water. The solution was then stored in a glass bottle. A lower concentration phosphorus solution was produced by diluting the stock solution with denionized (DI) water based on experimental designs.

Different experimental designs are presented in Table 1, outlining the impact of different calcination temperatures, sorbent dosages, and phosphorus concentrations on efficiency of phosphorus removal. All experimental phosphorus solution volumes were set at $150 \mathrm{~mL}$ in $250 \mathrm{~mL}$ glass beakers at room temperature under a constant $200 \mathrm{rpm}$ magnetic stirring rate. The phosphorus removal efficiency was recorded at different contact times of 1,3, 7, 10, 20, and $60 \mathrm{~min}$. After treatment, the solutions were filtered through a syringe filter $(0.45 \mu \mathrm{m})$ to separate precipitates. Phosphorus concentration was analyzed by HS 3300 spectrophotometer (HUMAS, Korea) at a $880 \mathrm{~nm}$ wavelength. The phosphorus 
removal efficiency (E) and adsorption capacity $\left(q_{e}\right)$ were calculated using Equations (1) and (2), respectively [30]:

$$
\begin{gathered}
\mathrm{E}(\%)=\frac{C_{0}-C_{e}}{C_{0}} \times 100 \\
q_{e}(\mathrm{mg} / \mathrm{g})=\frac{V\left(C_{0}-C_{e}\right)}{W}
\end{gathered}
$$

where $C_{e}(\mathrm{mg} \mathrm{TP} / \mathrm{L})$ denotes the equilibrium concentration of the remaining phosphorus after treatment, $C_{0}(\mathrm{mg} \mathrm{TP} / \mathrm{L}$ ) denotes the initial concentration of total phosphorus, $V(\mathrm{~L})$ is the volume of phosphorus solution, and $W(\mathrm{~g})$ is the weight of the calcite mud.

\begin{tabular}{|c|c|c|c|}
\hline Parameter & Value & Experiment & onditions \\
\hline \multirow{3}{*}{$\begin{array}{l}\text { Calcination } \\
\text { temperature } \\
\left({ }^{\circ} \mathrm{C}\right)\end{array}$} & 0 & \multirow{3}{*}{$\begin{array}{c}\text { Phosphorus concentration }= \\
15 \mathrm{mg} \mathrm{TP} / \mathrm{L}, \text { Sorbent dosage }= \\
10 \mathrm{mg}\end{array}$} & \multirow{11}{*}{$\begin{array}{l}200 \mathrm{rpm} \text { of mixing speed, } \\
\text { room temperature }\left(25^{\circ} \mathrm{C}\right) \\
150 \mathrm{~mL} \text { volume of phosphorus } \\
\text { solution }\end{array}$} \\
\hline & 800 & & \\
\hline & 1000 & & \\
\hline \multirow{4}{*}{$\begin{array}{l}\text { Sorbent dosage } \\
\quad(\mathrm{mg})\end{array}$} & 4.5 & \multirow{4}{*}{$\begin{array}{c}\text { Phosphorus concentration }= \\
15 \mathrm{mg} \mathrm{TP} / \mathrm{L}, \text { Calcite mud calcined } \\
\text { at } 1000{ }^{\circ} \mathrm{C}\end{array}$} & \\
\hline & 6.75 & & \\
\hline & 9 & & \\
\hline & 11.25 & & \\
\hline \multirow{4}{*}{$\begin{array}{l}\text { Phosphorus } \\
\text { concentration } \\
\text { (mg TP/L) }\end{array}$} & 5 & \multirow{4}{*}{$\begin{array}{l}\text { Sorbent dosage }=11.25 \mathrm{mg}, \\
\text { Calcite mud calcined at } 1000{ }^{\circ} \mathrm{C}\end{array}$} & \\
\hline & 15 & & \\
\hline & 30 & & \\
\hline & 60 & & \\
\hline
\end{tabular}

Table 1. Details of the different experimental conditions.

\subsection{Adsorption Kinetics}

Adsorption kinetic models can be estimated by the adsorption rate to express the reaction mechanisms. Pseudo-first-order (PFO), pseudo-second-order (PSO), and intraparticle diffusion (IPD) kinetic models are three kinetic models commonly employed. The linearized form of the PFO, PSO, and IPD kinetic models are derived in Equations (3)-(5), respectively [31-33]:

$$
\begin{aligned}
\log \left(q_{e}-q_{t}\right) & =-\left(\frac{k_{P F O}}{2.303}\right) t+\log \left(q_{e}\right) \\
\frac{t}{q_{t}} & =\left(\frac{1}{q_{e}}\right) t+\frac{1}{k_{P S O} q_{e}^{2}} \\
q_{t} & =k_{I P D} t^{1 / 2}+c
\end{aligned}
$$

where $k_{P F O}\left(\mathrm{~min}^{-1}\right), k_{P S O}\left(\mathrm{~g} \cdot \mathrm{mg}^{-1} \cdot \mathrm{min}^{-1}\right)$, and $k_{I D P}\left(\mathrm{mg} \cdot \mathrm{g}^{-1} \cdot \mathrm{min}^{-2}\right)$ are the rate constants of the PFO, PSO, and IPD models, respectively; and $q_{e}(\mathrm{mg} / \mathrm{g})$ and $q_{t}(\mathrm{mg} / \mathrm{g})$ are the adsorption capacity at the equilibrium and at time $(t)$ respectively.

To further investigate the characteristics of phosphorus adsorption of the calcite mud, Langmuir's and Freundlich's isotherm models were used. Langmuir's and Freundlich's isotherm models are expressed in Equations (6) and (7), respectively [31,33]. The experimental data, with a fixed dosage of calcite mud, $W=11.25 \mathrm{mg}$, and the initial phosphorus concentration, varied from 5 to $60 \mathrm{mg} / \mathrm{g}$, were used in the fitting isotherm models:

$$
q_{e}=\frac{q_{\max } \times k_{\text {Lang }} \times C_{e}}{1+k_{\text {Lang }} \times C_{e}}
$$




$$
q_{e}=k_{\text {Freu }} \times C_{e}{ }^{n}, \mathrm{n}<1
$$

where $k_{\text {Lang }}$ is Langmuir's constant; $q_{\max }(\mathrm{mg} / \mathrm{g})$ and $q_{e}(\mathrm{mg} / \mathrm{g})$ are the adsorption capacity at the maximum and equilibrium, respectively; and $k_{\text {Freu }}$ and $n$ are Freundlich's constants.

\subsection{Characterizations}

The crystals of the calcite mud waste and calcite mud samples at different calcination temperatures were observed using X-ray diffraction (XRD, BD2745N, Japan) with a $0.15406 \mathrm{~nm} \mathrm{Cu} \mathrm{K \alpha}$ source by ranging $2 \theta$ from $20^{\circ}$ to $80^{\circ}$. The crystallite size (D) of the calcined muds was estimated by Scherrer's equation, $\mathrm{D}=\mathrm{K} \lambda / \beta \cos \theta$, where $\mathrm{K}$ denotes Scherrer's constant, $\lambda$ denotes the wavelength of the $\mathrm{X}$-ray radiation, $\beta$ represents the haft-width of the diffraction peak, and $\theta$ stands for the Bragg diffraction angle. The morphology of the calcite muds was measured by scanning electron microscopy (SEM; JSM-6380F, Japan) equipment. The characteristic functional group of the muds was recorded by Fourier transform infrared spectroscopy (FTIR; 6700 FTIR, Thermo Scientific Nicolet, USA) in attenuated total reflection (ATR) mode with a range of $400-4000 \mathrm{~cm}^{-1}$.

\section{Results and Discussion}

\subsection{Characteristics of Muds}

To analyze the crystal structure properties of the calcite mud and the prepared muds, XRD was investigated. For raw calcite mud, all the diffraction peaks were assigned to calcite $\left(\mathrm{CaCO}_{3}\right)$, along with the pattern corresponding to PDF\#72-1937, as depicted in Figure 1. The XRD peaks marked by C at $23.03^{\circ}, 29.37^{\circ}, 35.93^{\circ}, 39.36^{\circ}, 43.11^{\circ}, 47.44^{\circ}, 48.45^{\circ}, 56.5^{\circ}, 57.34^{\circ}, 60.6^{\circ}$, and $64.59^{\circ} 2 \theta$ responded to the (012), (104), (110), (113), (202), (018), (116), (211), (122), (214), and (300) planes of the calcite phase (PDF\#72-1937), respectively [30]. The XRD patterns of the mud calcined at $800{ }^{\circ} \mathrm{C}$ (blue line) and $1000{ }^{\circ} \mathrm{C}$ (red line) are also presented in Figure 1. The results showed that the major peaks of the calcined muds matched very well with the cubic lime crystal phase (calcium oxide) (PDF\#82-1690). The peaks marked by an asterisk at $32.24^{\circ}, 37.4^{\circ}, 53.92^{\circ}, 64.24^{\circ}$, and $67.46^{\circ} 2 \theta$ correspond to the (111), (200), (220), (311), and (222) planes of the calcium oxide phase (PDF\#82-1690), respectively. The XRD peaks of the calcite mud calcined at $1000{ }^{\circ} \mathrm{C}$ (intensity $=2530$ a.u.) were sharper and stronger in intensity than the peaks of the mud calcined at $800{ }^{\circ} \mathrm{C}$ (intensity $=2236$ a.u.). The estimated average crystal size of calcined muds for all planes was about $39.75 \mathrm{~nm}$ for mud calcined at $800{ }^{\circ} \mathrm{C}$ and $41.11 \mathrm{~nm}$ for mud calcined at $1000{ }^{\circ} \mathrm{C}$. The results showed that the crystallinity of the calcined mud improved, and the crystallite size increased with increasing calcination temperature.

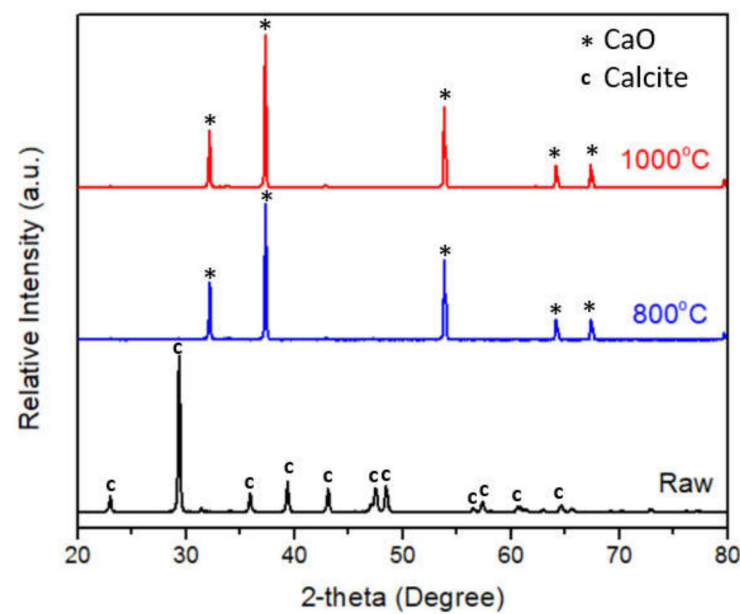

Figure 1. XRD results of the raw calcite mud (black line), calcite mud at $800{ }^{\circ} \mathrm{C}$ (blue line), and calcite mud at $1000{ }^{\circ} \mathrm{C}$ (red line). 
Regarding the representative functional groups, FTIR analysis was applied. Figure 2 shows the FTIR patterns of calcite mud before and after heat treatment. The FTIR analysis of calcite mud showed sharp and intense vibration peaks at 712,871, and $1426 \mathrm{~cm}^{-1}$, which are attributed to $v_{4}$ (in-plane bending mode), $v_{2}$ (out-of-plane bending mode), and $v_{3}$ (antisymmetric stretching mode) of the $\mathrm{CO}_{3}{ }^{2-}$ group of the calcite, respectively (Figure 2a) [34]. However, after calcination treatment, the FTIR patterns of the mud were not observed in any carbonated group, as shown in Figure $2 \mathrm{~b}$. The wide band around $500 \mathrm{~cm}^{-1}$ corresponds to the $\mathrm{Ca}-\mathrm{O}$ bonds in the calcined muds $[35,36]$. These FTIR results showed the effect of the adsorption process in the conversion of calcite, $\mathrm{CaCO}_{3}$, to calcium oxide, $\mathrm{CaO}$, through high-temperature treatment.

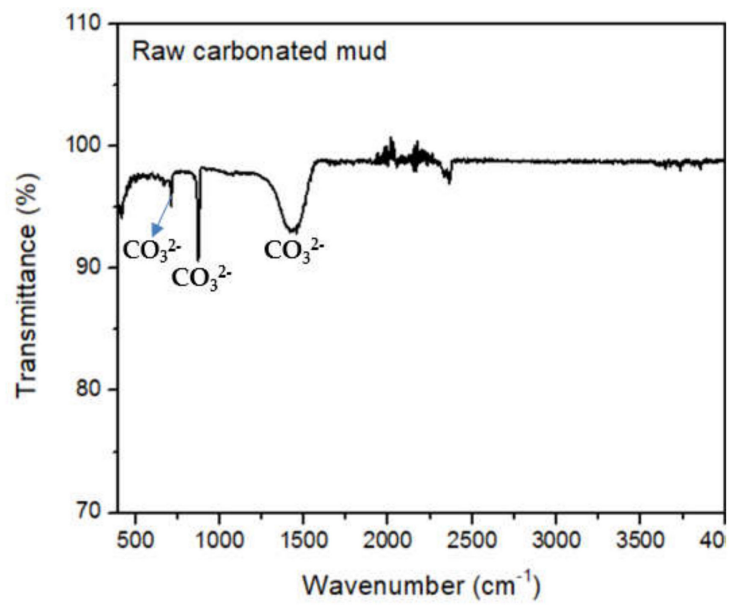

(a)

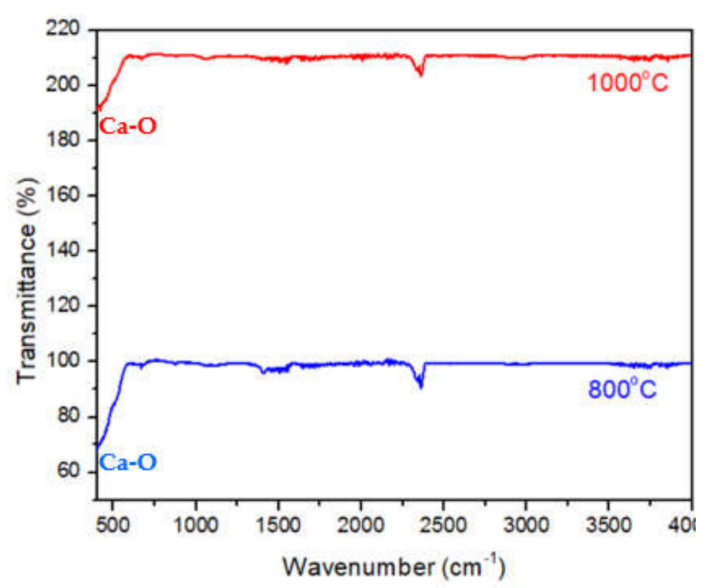

(b)

Figure 2. FTIR results for (a) the raw calcite mud and (b) the calcite mud calcined at $800{ }^{\circ} \mathrm{C}$ (blue line), and at $1000^{\circ} \mathrm{C}$ (red line).

The SEM images of calcite mud before and after heat treatment are presented in Figure 3. The raw calcite mud in the micrograph shows agglomerate units, irregular shape, and amorphous-like particles with a size range of $300 \mathrm{~nm}^{-1} \mu \mathrm{m}$ (Figure 3a). The morphology of calcite mud with the additive sintered at $1000{ }^{\circ} \mathrm{C}$ is illustrated in Figure $3 \mathrm{~b}$. It was converted to calcium oxide $(\mathrm{CaO})$ when calcinated at $1000{ }^{\circ} \mathrm{C}$ because the $\mathrm{CO}_{2}$ gas was removed. The micrograph clearly shows new crystals of calcium oxide and separated particles. The shape of the $\mathrm{CaO}$ particles is irregularly hexagonal, with a size range of $2-4 \mu \mathrm{m}$. The $\mathrm{CaO}$ particle size became much larger due to the aggregation of $\mathrm{CaO}$ particles, perhaps due to the influence of the high temperature during the calcination process.
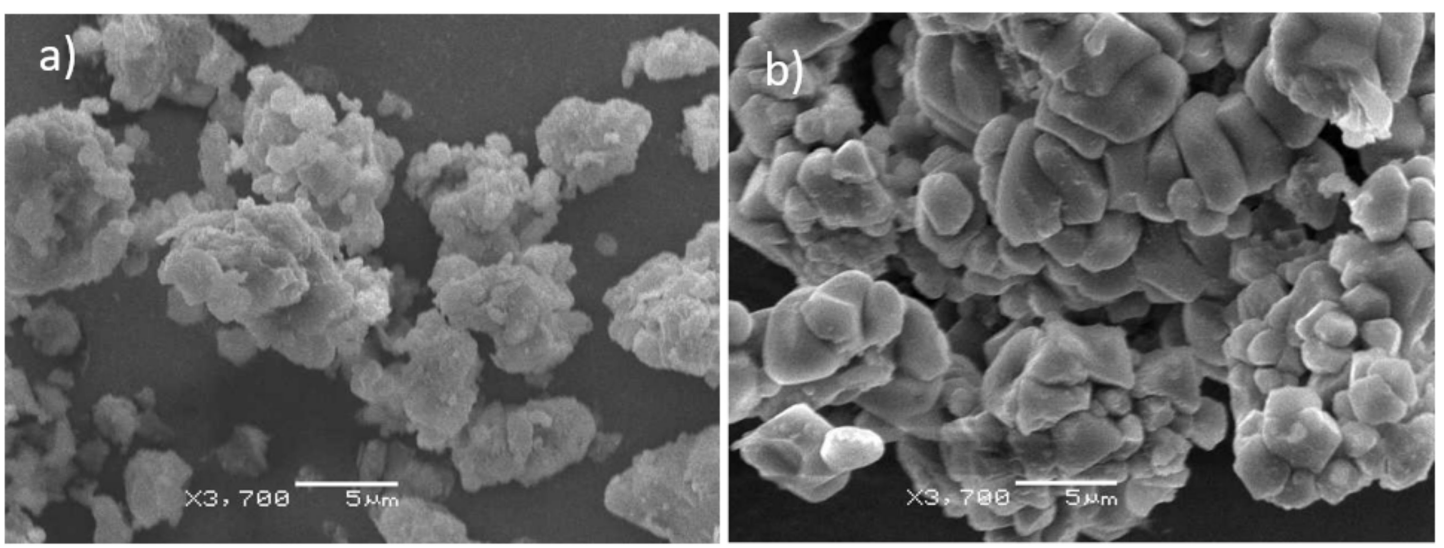

Figure 3. SEM images of (a) raw calcite mud and (b) calcite mud calcined at $1000{ }^{\circ} \mathrm{C}$. 


\subsection{Phosphorus Removal}

The effect of heat treatment on the efficiency of phosphorus removal was investigated. Raw calcite mud, calcite mud calcined at $800{ }^{\circ} \mathrm{C}$, and calcite mud calcined at $1000^{\circ} \mathrm{C}$ showed phosphorus removal efficiencies of $0 \%, 87.2 \%$, and $100 \%$ within $60 \mathrm{~min}$, respectively. The results showed that the efficiency of phosphorus removal increased significantly with increasing calcination temperature due to increasing calcium oxide quality in the samples. Therefore, the sample of calcite mud calcined at $1000{ }^{\circ} \mathrm{C}$ was used for further experiments to check the effect of dosage, contact time, and phosphorus concentration on the efficiency of phosphorus removal.

To research the effect of adsorbent dosage on the efficiency of phosphorus removal, different amounts of calcite mud, calcined at $1000^{\circ} \mathrm{C}(4.5,6.75,9$, and $11.25 \mathrm{mg})$, were added into a phosphorus solution of $150 \mathrm{~mL}$ with a constant phosphorus concentration of $15 \mathrm{mg} \mathrm{TP} / \mathrm{L}$. The phosphorus removal efficiency depended on the adsorbent dosage, as shown in Figure 4 . The efficiency increased from $35.3 \%$ to $100 \%$ within $60 \mathrm{~min}$ when the calcite mud dosage was raised from 4.5 to $11.25 \mathrm{mg}$. The efficiency of phosphorus removal increased with increasing adsorbent dosage. This trend was also observed in various other studies on phosphorus removal. Torit et al. showed that the efficiency of phosphorus removal increased from $9 \%$ to $25 \%$ with increasing eggshell ash from 1 to $5 \mathrm{~g}$ [37]. The phosphorus removal efficiency was increased from $3 \%$ to $100 \%$ as the weight of lime sludge increased from 0.6 to $4.0 \mathrm{~g} / \mathrm{L}$ at $75 \mathrm{mg} \mathrm{TP} / \mathrm{L}$ phosphorus concentration within $30 \mathrm{~min}$ [38].

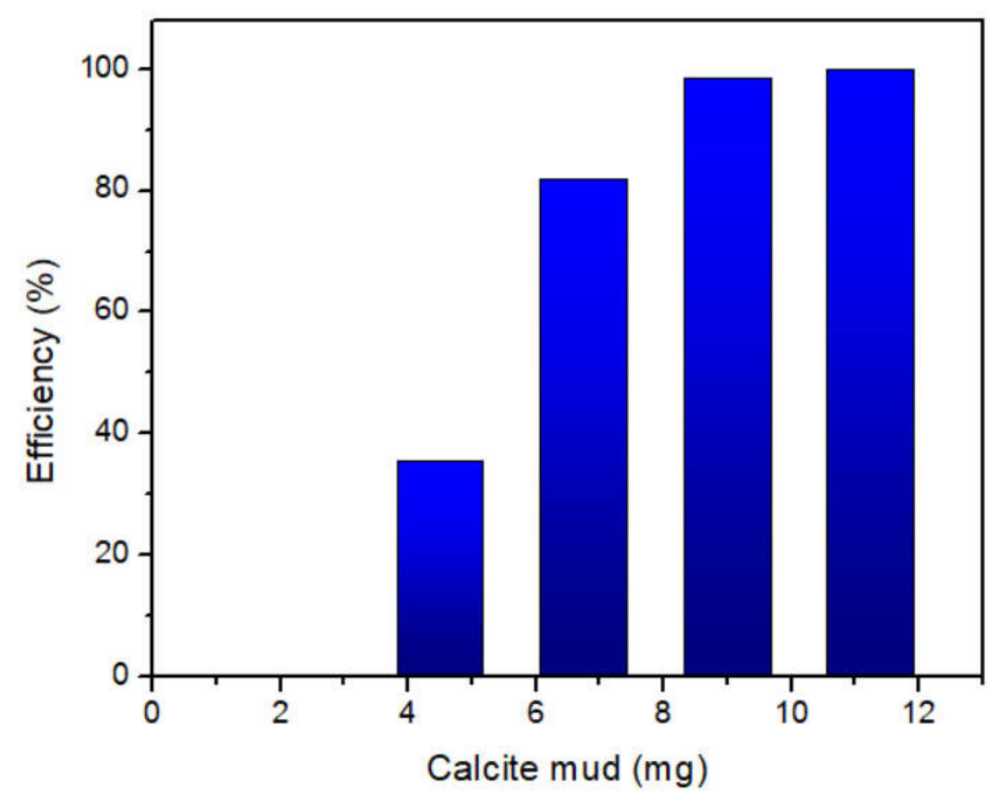

Figure 4. Effect of calcite mud (calcined at $1000{ }^{\circ} \mathrm{C}$ ) dosage on phosphorus removal within $60 \mathrm{~min}$.

Figure 5a shows the effect of contact time on the efficiency of phosphorus removal. These experiments were performed with different calcite mud (calcined at $1000^{\circ} \mathrm{C}$ ) dosages in a phosphorus concentration of $15 \mathrm{mg} \mathrm{TP} / \mathrm{L}$, and the efficiencies were recorded at different time intervals. The results showed that the phosphorus removal rate rose very quickly within the initial $7 \mathrm{~min}$ of contact time due to the fresh active sorption sites on the surface of the sorbent, and then slowly increased until reaching equilibrium in $10 \mathrm{~min}$, suggesting that the phosphorus ions, being full, filled out into the active sites on the surface of sorbent $[30,37]$. The phosphorus adsorption rate is presented in Figure $5 \mathrm{~b}$. The data showed that the adsorption capacity increased until chemical equilibrium, and the best adsorption capacity, $197.4 \mathrm{mg} / \mathrm{g}$, was reached within $3 \mathrm{~min}$ at $11.25 \mathrm{mg}$ of calcite mud calcined at $1000{ }^{\circ} \mathrm{C}$. 


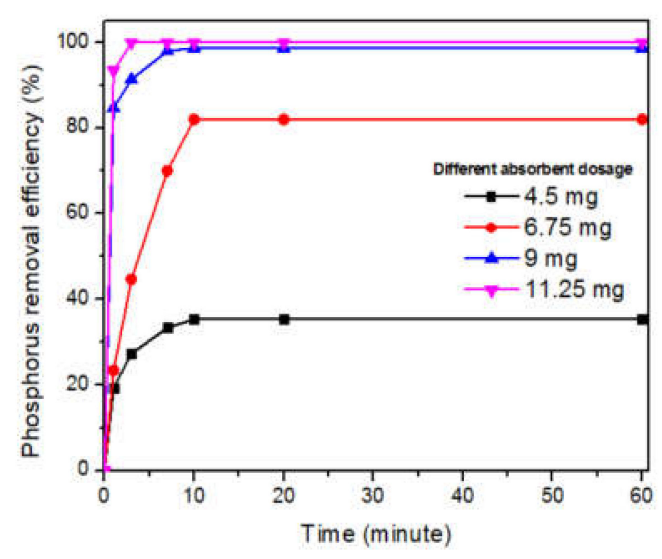

(a)

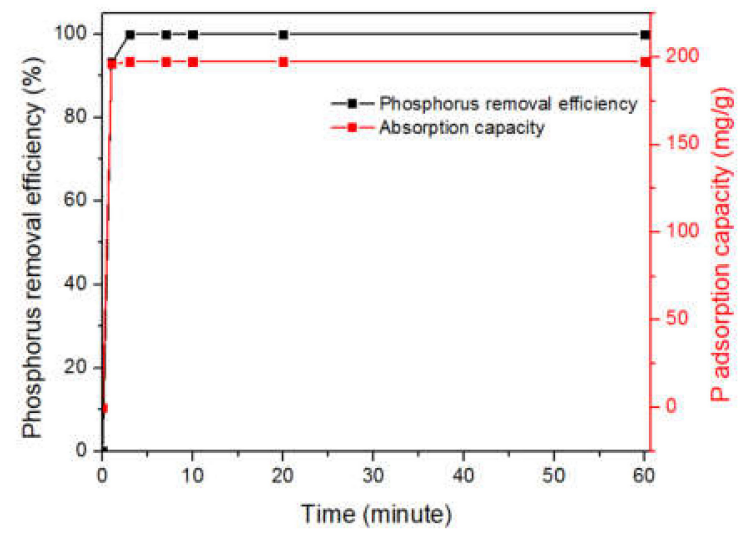

(b)

Figure 5. (a) Effects of contact time on the efficiency of phosphorus removal, (b) kinetic studies of phosphorus adsorption by $11.25 \mathrm{mg}$ of calcite mud calcined at $1000{ }^{\circ} \mathrm{C}$.

The effect of phosphorus concentration on the efficiency of phosphorus removal is presented in Figure 6. Four initial phosphorus concentration experiments were performed in $150 \mathrm{~mL}$ of solution with a constant dosage $11.25 \mathrm{mg}$ of calcite mud calcined at $1000{ }^{\circ} \mathrm{C}$. The efficiency of phosphorus removal was $100 \%$ within $10 \mathrm{~min}$ in the initial phosphorus concentrations of $5 \mathrm{mg} \mathrm{TP} / \mathrm{L}$ and $15 \mathrm{mg}$ $\mathrm{TP} / \mathrm{L}$. However, the efficiency decreased with higher phosphorus concentrations due to there being more phosphorus ions than sorption sites on the surface of the sorbent.

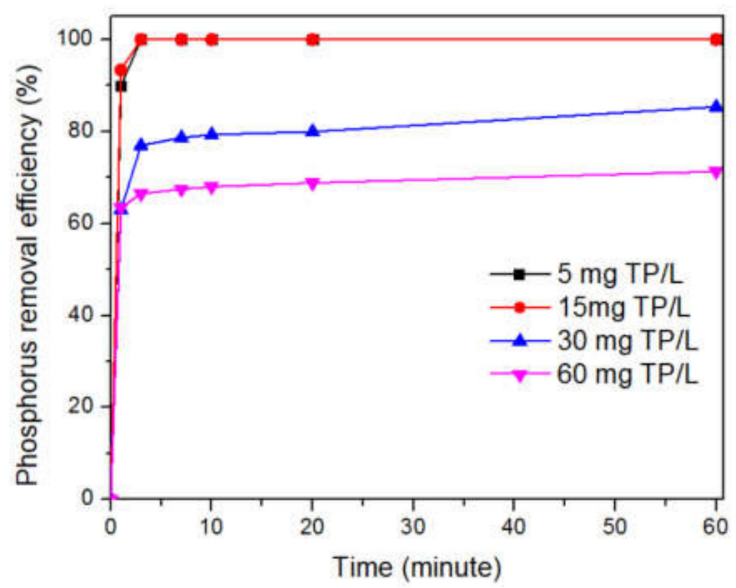

Figure 6. Effect of phosphorus concentration on the efficiency of phosphorus removal.

The phosphorus removal efficiency decreases when the solid retention time increases due to the biomass yield rate, according to the United States Environmental Protection Agency report. In this study, the highest phosphorus removal efficiency $(100 \%)$ with $11.25 \mathrm{mg}$ of adsorbent was obtained from 3 to $60 \mathrm{~min}$ of contact time. After this time, the efficiency of phosphorus decreases due to phosphorus desorption. The retention time of phosphorus in this study was $60 \mathrm{~min}$.

\subsection{Adsorption Kinetics}

The linearized forms of the PFO, PSO, and IPD models of the phosphorus adsorption concentration (Figure 7a), with the initial phosphorus concentrations $\left(C_{0}\right)$ of $30 \mathrm{mg} / \mathrm{g}$ and calcite mud $(W)$ of $11.25 \mathrm{mg}$, are depicted in Figure $7 \mathrm{~b}-\mathrm{d}$, respectively. Together, these show that the PSO model provides the best fitting. Thus, the adsorption mechanism was dominated by chemisorption. The fitting parameters of 
the models are shown in Table 2, in which the fitting correlation coefficient, $R^{2}$, was the highest for the PSO model, at 0.9995 . The $R^{2}$ for the PFO and IPD models were 0.614 and 0.7837 , respectively.
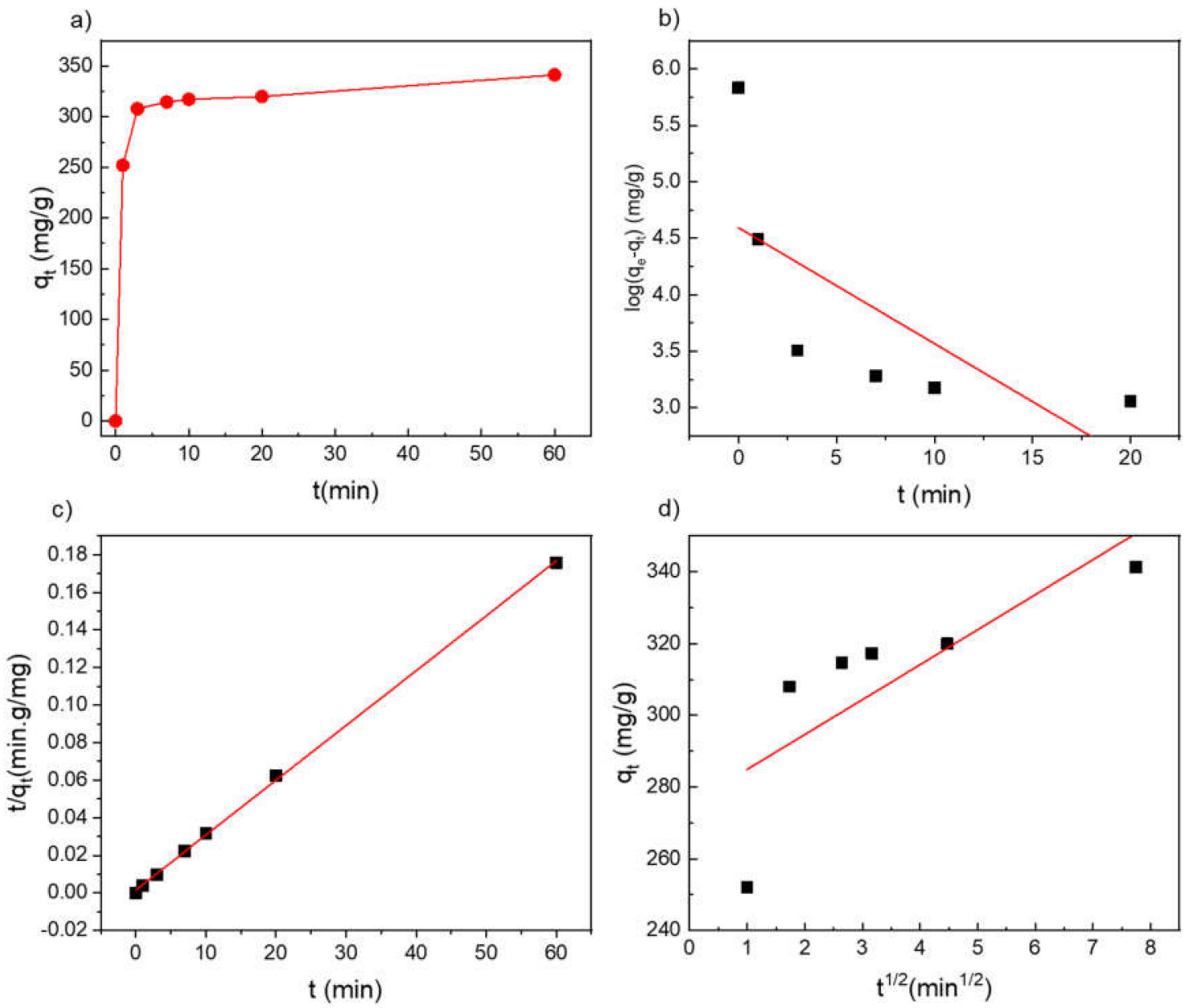

Figure 7. Adsorption capacity $\left(q_{t}\right)$ versus time $(t)$ of the phosphorus (a) and linearized kinetic models of the pseudo-first-order (PFO) (b), pseudo-second-order (PSO) (c), and intraparticle diffusion (IPD) (d).

Table 2. Fitting parameters of linearized kinetic models.

\begin{tabular}{cccc}
\hline Kinetic Models & Fitting Parameters & Unit & Values \\
\hline \multirow{2}{*}{$\begin{array}{c}\text { Pseudo-first-order model } \\
\text { (PFO) }\end{array}$} & $q_{e}$ & $\mathrm{mg} / \mathrm{g}$ & 98.79 \\
\cline { 2 - 4 } & $k_{P F O}$ & $\mathrm{~min}^{-1}$ & 4.234 \\
\cline { 2 - 4 } & $R^{2}$ & & 0.614 \\
\hline $\begin{array}{c}\text { Pseudo-second-order model } \\
\text { (PSO) }\end{array}$ & $q_{e}$ & $\mathrm{mg} / \mathrm{g}$ & 342.47 \\
\cline { 2 - 4 } & $k_{P S O}$ & $\mathrm{~g} \cdot \mathrm{mg}^{-1} \cdot \mathrm{min}^{-1}$ & 0.0055 \\
\hline \multirow{2}{*}{$\begin{array}{c}R^{2} \\
\text { Intraparticle diffusion model } \\
\text { (IPD) }\end{array}$} & $\mathrm{c}$ & & 0.9995 \\
\cline { 2 - 4 } & $k_{I P D}$ & $\mathrm{mg} \cdot \mathrm{g}^{-1} \cdot \mathrm{min}^{-2}$ & 9.751 \\
\cline { 2 - 4 } & $R^{2}$ & & 0.7837 \\
\hline
\end{tabular}

Because the PSO kinetic model provided the best fitting model, we used it to analyze the effect of initial phosphorus concentrations and the amount of calcite mud on the adsorption capacity. We changed the initial phosphorus concentration to a range of 5-60 mg TP/L, and the weight of calcite 
mud to a range of $4.5-11.25 \mathrm{mg}$. The fitting of the PSO model is shown in Figure 8. The fitting parameters of the models are shown in Table 3. The $R^{2}$ values of all the fitting lines were very close to 1.0000 , which means the PSO model represents the adsorption capacity of phosphorus very well. In addition, the estimated adsorption at the equilibriums agreed with the experimental data, with a normalized root mean square deviation (NRMSD) of $1.25 \%(7.16 \mathrm{mg})$.
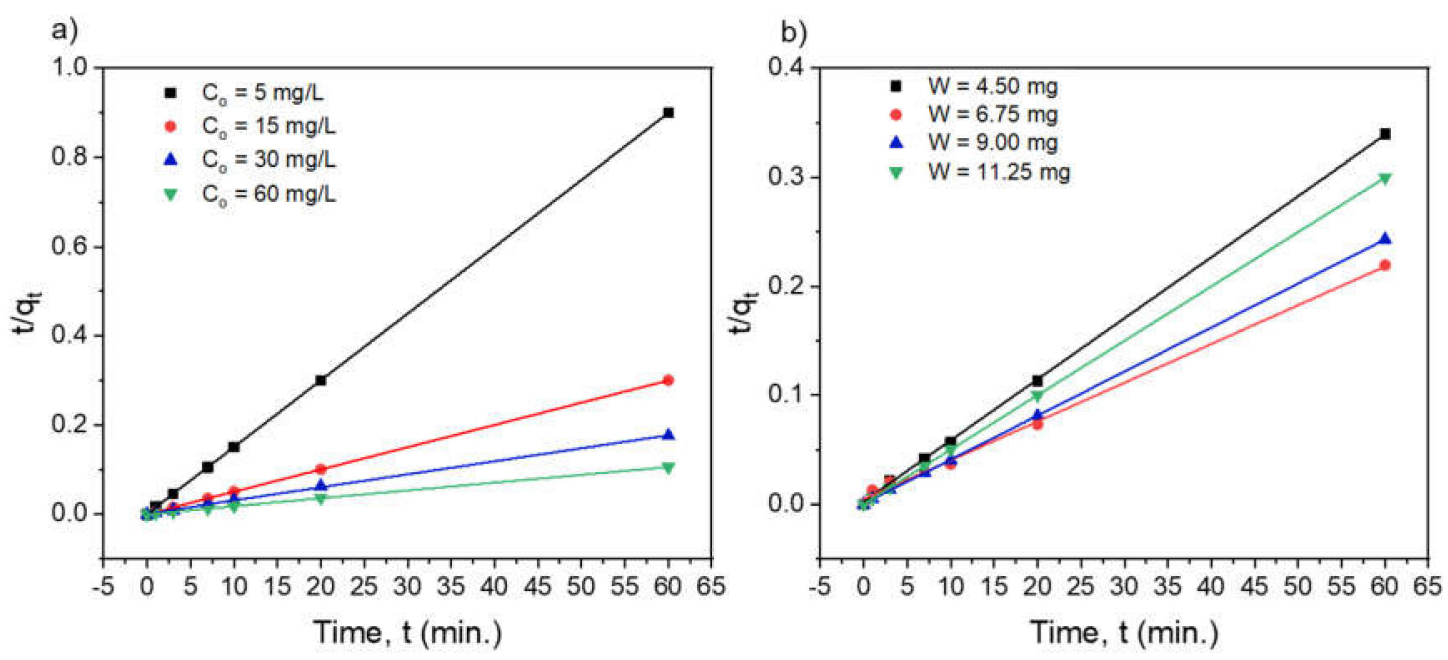

Figure 8. Linearized form of the PSO kinetic model with variations of the initial phosphorus concentration, $C_{o},(\mathbf{a})$ and amount of the calcite mud used, $W(\mathbf{b})$.

Table 3. Fitting parameters of the PSO model on different initial phosphorus concentrations $\left(C_{o}\right)$ and amount of calcite mud used $(W)$.

\begin{tabular}{|c|c|c|c|c|c|}
\hline \multicolumn{2}{|c|}{$\begin{array}{l}\text { Experimental } \\
\text { Conditions }\end{array}$} & \multirow{2}{*}{$\begin{array}{c}q_{e}(\text { Experiment) } \\
(\mathrm{mg} / \mathrm{g})\end{array}$} & \multirow{2}{*}{$\begin{array}{c}\begin{array}{c}q_{e} \\
\text { (Model) } \\
\text { (mg/g) }\end{array} \\
66.67 \\
\end{array}$} & \multirow{2}{*}{$\begin{array}{c}\begin{array}{c}k_{P S O} \\
\left(\mathrm{~g} \cdot \mathrm{mg}^{-\mathbf{1}} \cdot \mathbf{m i n}^{-\mathbf{1}}\right)\end{array} \\
0.5625\end{array}$} & \multirow{2}{*}{$\begin{array}{c}R^{2} \\
1.0000\end{array}$} \\
\hline $\mathrm{C}_{\mathrm{o}}=5(\mathrm{mg} \mathrm{TP} / \mathrm{L})$ & \multirow{4}{*}{$\mathrm{W}=11.25(\mathrm{mg})$} & & & & \\
\hline $\mathrm{C}_{\mathrm{o}}=15(\mathrm{mg} \mathrm{TP} / \mathrm{L})$ & & 200.00 & 200.00 & 0.3125 & 1.0000 \\
\hline $\mathrm{C}_{\mathrm{o}}=30(\mathrm{mg} \mathrm{TP} / \mathrm{L})$ & & 341.33 & 344.83 & 0.0057 & 0.9995 \\
\hline $\mathrm{C}_{\mathrm{o}}=60(\mathrm{mg} \mathrm{TP} / \mathrm{L})$ & & 570.67 & 588.24 & 0.0006 & 0.9998 \\
\hline $\mathrm{W}=4.50(\mathrm{mg})$ & \multirow{4}{*}{$\mathrm{Co}=15(\mathrm{mg} \mathrm{TP} / \mathrm{L})$} & 176.67 & 178.57 & 0.0128 & 0.9997 \\
\hline $\mathrm{W}=6.75(\mathrm{mg})$ & & 273.33 & 277.7778 & 0.0029 & 0.9974 \\
\hline $\mathrm{W}=9.00(\mathrm{mg})$ & & 246.67 & 250.00 & 0.0041 & 1.0000 \\
\hline $\mathrm{W}=11.25(\mathrm{mg})$ & & 200.00 & 200.00 & 0.3125 & 1.0000 \\
\hline
\end{tabular}

The results in Table 3 show that the fitting parameters of the PSO kinetic model are different at the different experimental conditions. Usually, we expect to predict the adsorption capacity $\left(C_{e}\right)$ at the equilibrium state when designing the experiment conditions; , for instance, the amount of $C_{e}$ with a certain $C_{o}$ and $W$. Further analysis based on the predicted $q_{e}$ of the PSO models was conducted as shown in Figure 9. Figure 9a shows that the predicted $q_{e}$ had a linear relationship with the $C_{0}$. The relationship is described in Equation (8), with the fitting correlation coefficient $R^{2}$ of 0.9899 . The increase in $q_{e}$ was about nine times the increase in $C_{0}$, which meant that the proposed adsorption method was efficient. We think that the increase in $q_{e}$ would reach an equilibrium saturation state when all the calcite mud was fully reacted. However, $q_{e}$ reaches a peak when increasing the amount of calcite mud, $W$, as depicted in Figure $9 \mathrm{~b}$. The peak is at about $7 \mathrm{mg}$ of the calcite mud with an initial phosphorus concentration of $15 \mathrm{mg} \mathrm{TP} / \mathrm{L}$. This phenomenon could be explained by the adsorption capacity achieving the maximum value when all the phosphorus was adsorbed or the adsorption efficiency of the calcite mud reached the maximum value; $q_{e}$ is inversely proportional to the amount 
of supplied calcite mud. Figure 9 also shows that the predicted $q_{e}$ of the PSO model agreed with the experimental data, as shown in Table 4.

$$
q_{e}=9.26 \times C_{o}+45.18
$$
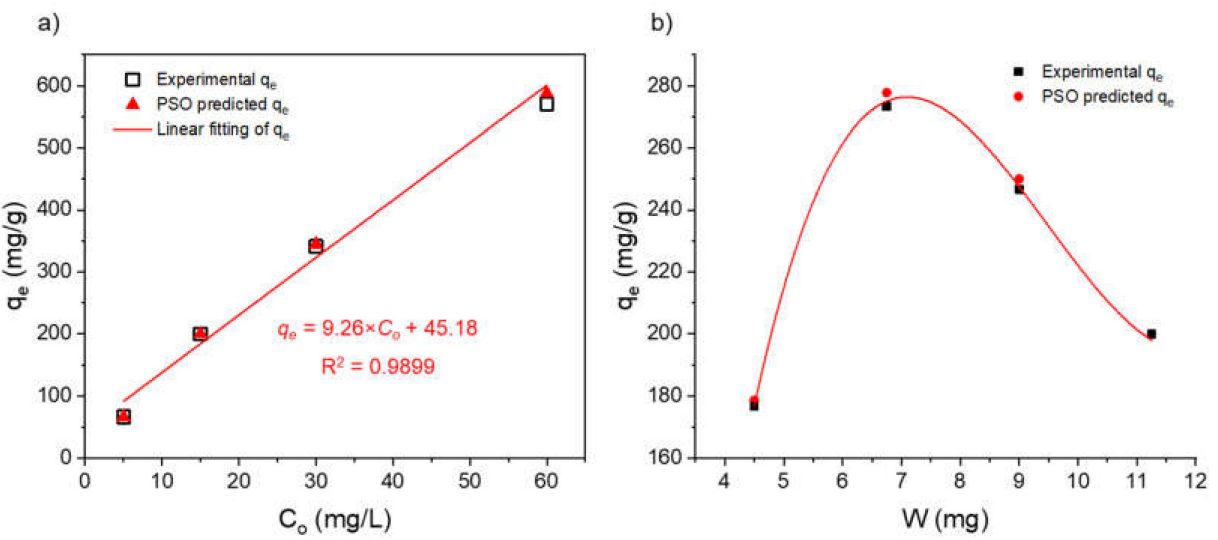

Figure 9. The relationship between adsorption capacity at the equilibrium with the initial phosphorus concentration, $C_{o}(\mathbf{a})$, and amount of calcite mud used, $W(\mathbf{b})$.

Table 4. Fitting parameters of Langmuir's and Freundlich's isotherm models.

\begin{tabular}{ccc}
\hline Kinetic Models & Fitting Parameters & Values \\
\hline \multirow{2}{*}{ Langmuir's isotherm model } & $q_{\text {max }}$ & $851.42 \mathrm{mg} / \mathrm{g}$ \\
\cline { 2 - 3 } & $k_{\text {Lang }}$ & 0.9820 \\
\cline { 2 - 3 } & $R^{2}$ & 0.9545 \\
\cline { 2 - 3 } Freundlich's isotherm model & $\mathrm{n}$ & 0.57967 \\
\cline { 2 - 3 } & $k_{\text {Freu }}$ & 387.11 \\
\hline
\end{tabular}

The fitting graphs in Figure 10 show good fitting by the Langmuir model. The $R^{2}$ of Langmuir's and Freundlich's models were 0.9545 and 0.9474 , respectively. The maximum adsorption capacity $\left(q_{\max }\right)$ could be predicted by Langmuir's model as $851.42 \mathrm{mg} / \mathrm{g}$. The high adsorption capability of the mud on the phosphorus was a monolayer, and the major adsorption mechanism was chemisorption.

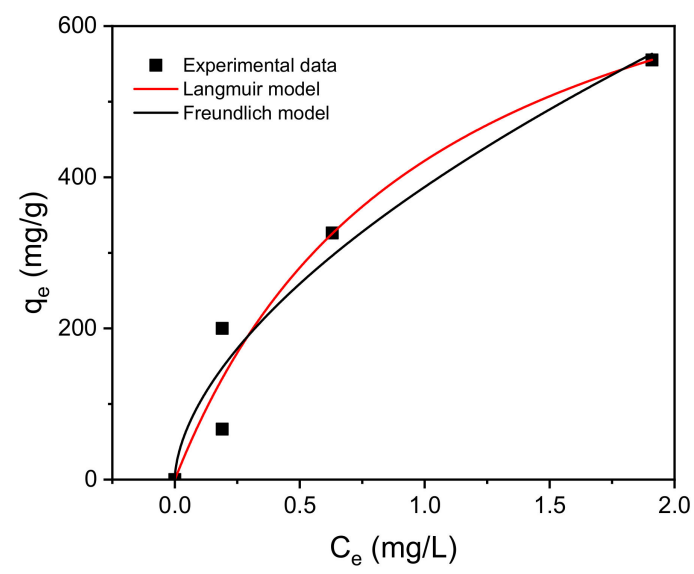

Figure 10. Fitting of Langmuir's and Freundlich's isotherm models of the phosphorus on the calcium mud. 
In this study, the method efficiently removed $100 \%$ of the phosphorus at a concentration of $15 \mathrm{mg}$ $\mathrm{TP} / \mathrm{L}$ within $60 \mathrm{~min}$. This is comparable to the crystallized method, with $95.82 \%$ efficiency using hydroxyapatite $\left(\mathrm{Ca}_{10}\left(\mathrm{PO}_{4}\right)_{6}(\mathrm{OH})_{2}\right)$ [19], and the chemical precipitation method, with $99 \%$ efficiency, using mussel shells [25]. This method also produced no side effects, whereas the other metal salts method produce metal ions (e.g., $\mathrm{Al}^{3+}, \mathrm{Fe}^{3+}$ ) and anions (e.g., $\mathrm{SO}_{4}{ }^{2-}, \mathrm{Cl}^{-}$) [39-43]. The results of this study showed that the employment of pre-treated mud could be effective in removing phosphorus from wastewater. Another benefit of this method is that it provides a use for the discharged calcite mud from industrial factories.

\section{Conclusions}

In this work, a method for phosphorus removal by calcined calcite mud was proposed. We used a simple heat treatment method to synthesize $\mathrm{CaO}$ from the calcite mud, later used for removing the phosphorous in the wastewater. The calcite mud calcined at $1000{ }^{\circ} \mathrm{C}$ as a sorbent showed the most efficient phosphorus removal. The phosphorus removal efficiency increased with increasing sorbent dosage up to $11.25 \mathrm{mg}$ and decreased with increasing initial phosphorus concentration (higher than $15 \mathrm{mg} \mathrm{TP} / \mathrm{L}$ ). The phosphorus adsorption capacity was studied with the pseudo-first-order, pseudo-second-order, and intraparticle diffusion kinetic models. Among the three kinetic models, the pseudo-second-order model provided the best fitting with the experiment data by a fitting correlation coefficient $\left(R^{2}\right)$ of 0.9995 . In addition, Langmuir's model fitted well with the experimental results. Therefore, the high adsorption capability of the calcite mud on the phosphorus was a monolayer, and the major adsorption mechanism was chemisorption.

Author Contributions: H.H.T.V. and M.D.K. planned and designed the experiment; H.H.T.V. and V.T.T. carried out the experiments; H.H.T.V., S.L., and D.V.Q. analyzed the data and wrote the paper; J.W.A., S.-h.J., and V.-D.D. reviewed and revised the manuscript. All authors have read and agreed to the published version of the manuscript.

Funding: This research was supported by the National Strategic Project-Carbon upcycling of the National Research Foundation of Korea (NRF) funded by the Ministry of Science and ICT (MSIT), the Ministry of Environment (ME), and the Ministry of Trade, Industry, and Energy (MOTIE) (2019M3D8A2112963). This research also supported by The Phenikaa University Foundation for Science and Technology Development.

Conflicts of Interest: The authors declare no conflict of interest.

\section{References}

1. Ott, C.; Degg, A.; Walke, P.; Reiter, F.; Nilges, T. Influence of copper on the capacity of phosphorus-anode in sodium-ion-batteries. J. Solid State Chem. 2019, 270, 636-641. [CrossRef]

2. Puijenbroek, P.J.T.M.V.; Beusen, A.H.W.; Bouwman, A.F. Datasets of the phosphorus content in laundry and dishwasher detergents. Data Brief 2018, 21, 2284-2289. [CrossRef] [PubMed]

3. Eussen, S.R.B.; Verhagen, H.; Klungel, O.H.; Garssen, J.; Loveren, H.V.; Henk, J.V.K.; Rompelberg, C.J.M. Functional foods and dietary supplements: Products at the interface between pharma and nutrition. Eur. J. Pharmacol. 2011, 668, 2-9. [CrossRef] [PubMed]

4. Harrison, R.M. Pollution: Causes, Effects, and Control, 3rd ed.; The Royal Society of Chemistry: London, UK, 1996.

5. Kiely, G. Environmental Engineering; McGraw Hill: New York, NY, USA, 1997.

6. Chen, M.; Chen, J.; Sun, F. Agricultural phosphorus flow and its environmental impacts in China. Sci. Total Environ. 2008, 405, 140-152. [CrossRef]

7. Withers, P.J.A.; Elser, J.J.; Hilton, J.; Ohtake, H.; Schipper, W.J.; Dijk, K.C. Greening the global phosphorus cycle: How green chemistry can help achieve planetary P sustainability. Green Chem. 2015, 17, 2087-2099. [CrossRef]

8. Zhao, S.; Xiao, J.; Zheng, T.; Liu, M.; Wu, H.; Liu, Z. Highly selective and sensitive detection of PO43-Ions in aqueous solution by a luminescent terbium metal-organic framework. ACS Omega 2019, 4, 16378-16384. [CrossRef]

9. Blaas, H.; Kroeze, C. Excessive nitrogen and phosphorus in European rivers: 2000-2050. Ecol. Indic. 2016, 67, 328-337. [CrossRef] 
10. Ding, S.; Chen, M.; Gong, M.; Fan, X.; Qin, B.; Xu, H.; Gao, S.S.; Jin, Z.; Tsang, D.C.W.; Zhang, C. Internal phosphorus loading from sediments causes seasonal nitrogen limitation for harmful algal blooms. Sci. Total Environ. 2018, 625, 872-884. [CrossRef]

11. Nandakumar, S.; Pipil, H.; Ray, S.; Haritash, A.K. Removal of phosphorus and nitrogen from wastewater in brachiaria-based constructed wetland. Chemosphere 2019, 233, 216-222. [CrossRef]

12. Troesch, S.; Esser, D.; Molle, P. Nature rock phosphate: A sustainable solution for phosphorus removal from wastewater. Procedia Eng. 2019, 138, 119-126. [CrossRef]

13. Monetti, J.; Ledezma, P.; Virdis, B.; Freguia, S. Nutrient recovery by bio-electro concentration is limited by wastewater conductivity. ACS Omega 2019, 4, 2152-2159. [CrossRef]

14. Dai, H.; Lu, X.; Peng, Y.; Yang, Z.; Zhu, H. Effects of supersaturation control strategies on hydroxyapatite (HAP) crystallization for phosphorus recovery from wastewater. Environ. Sci. Pollut. Res. 2017, 24, 5791-5799. [CrossRef] [PubMed]

15. Liu, B.; Nan, J.; Zu, X.; Zhang, X.; Huang, W.; Wang, W. La-based-adsorbents for efficient biological phosphorus treatment of wastewater: Synergistically strengthen of chemical and biological removal. Chemosphere 2020, 255, 127010. [CrossRef] [PubMed]

16. Zou, H.; Wang, Y. Phosphorus removal and recovery from domestic wastewater in a novel process of enhanced biological phosphorus removal coupled with crystallization. Bioresour. Technol. 2016, 211, 87-92. [CrossRef] [PubMed]

17. Mbamba, C.K.; Lindblom, E.; Alsina, X.F.; Tait, S.; Anderson, S.; Saagi, R.; Batstone, D.J.; Gernaey, K.V.; Jeppsson, U. Plant-wide model-based analysis of iron dosage strategies for chemical phosphorus removal in wastewater treatment systems. Water Res. 2019, 155, 12-25. [CrossRef] [PubMed]

18. Zheng, X.L.; Sun, P.D.; Han, J.Y.; Song, Y.Q.; Hu, Z.R.; Fan, H.Q.; Lv, S.Y. Inhibitory factors affecting the process of enhanced biological phosphorus removal (EBPR)-A mini-review. Proc. Biochem. 2014, 49, 2207-2213. [CrossRef]

19. Dai, H.L.; Lu, X.W.; Peng, Y.H.; Zou, H.M.; Shi, J. An efficient approach for phosphorus recovery from wastewater using series-coupled air-agitated crystallization reactors. Chemosphere 2016, 165, 211-220. [CrossRef]

20. Qiu, L.P.; Wang, G.W.; Zhang, S.B.; Yang, Z.X.; Li, Y.B. An approach for phosphate removal with quartz sand, ceramsite, blast furnace slag and steel slag as seed crystal. Water Sci. Technol. 2012, 65, 1048-1053. [CrossRef]

21. Bi, W.; Li, Y.Y.; Hu, Y.Y. Recovery of phosphorus and nitrogen from alkaline hydrolysis supernatant of excess sludge by magnesium ammonium phosphate. Bioresour. Technol. 2014, 166, 1-8. [CrossRef]

22. Ye, Z.L.; Shen, Y.; Ye, X.; Zhang, Z.J.; Chen, S.H.; Shi, J.W. Phosphorus recovery from wastewater by struvite crystallization: Property of aggregates. J. Environ. Sci. 2014, 26, 991-1000. [CrossRef]

23. Yang, M.; Shi, J.; Xu, Z.; Zhu, S.; Cui, Y. Phosphorus removal and recovery from Fosfomycin pharmaceutical wastewater by the induced crystallization process. J. Environ. Manag. 2019, 231, 207-212. [CrossRef] [PubMed]

24. Zhang, J.; Bligh, M.W.; Liang, P.; Waite, T.D.; Huang, X. Phosphorus removal by in situ generated Fe (II): Efficacy, kinetics, and mechanism. Water Res. 2018, 136, 120-130. [CrossRef] [PubMed]

25. Xiong, J.; Quin, Y.; Islam, E.; Yue, M.; Wang, W. Phosphate removal from solution using powdered freshwater mussel shells. Desalination 2011, 276, 317-321. [CrossRef]

26. Namasivayam, C.; Sakoda, A.; Suzuki, M. Technical Note: Removal of phosphate by adsorption onto oyster shell powder-kinetic studies. J. Chem. Technol. Biotechnol. 2011, 80, 356-358. [CrossRef]

27. Wirojanagud, W.; Tantemsapya, N.; Tantriratna, P. Precipitation of heavy metals by lime mud waste of pulp and paper mill. Songklanakarin J. Sci. Technol. 2004, 26, 45-53.

28. Zhang, J.; Zheng, P.; Wang, Q. Lime mud from papermaking process as a potential ameliorant for pollutants at ambient conditions: A review. J. Clean. Prod. 2015, 103, 828-836. [CrossRef]

29. Qin, J.; Cui, C.; Cui, X.Y.; Hussain, A.; Yang, C.M. Preparation and characterization of ceramsite from lime mud and coal fly ash. Constr. Build. Mater. 2015, 95, 10-17. [CrossRef]

30. Vu, H.H.T.; Khan, M.D.; Chilakala, R.; Lai, T.Q.; Thenepalli, T.; Ahn, J.W.; Park, D.U.; Kim, J. Utilization of lime mud waste from paper mills for efficient phosphorus removal. Sustainability 2019, 11, 1524. [CrossRef]

31. Habte, L.; Shiferaw, N.; Khan, M.D.; Thriveni, T.; Ahn, J.W. Sorption of Cd2+ and Pb2+ on aragonite synthesized from eggshell. Sustainability 2020, 12, 1174. [CrossRef] 
32. Robati, D. Pseudo-second-order kinetic equations for modeling adsorption systems for removal of lead ions using multiwalled carbon nanotube. J. Nanostruct. Chem. 2013, 3, 1-6. [CrossRef]

33. Tran, C.V.; Quang, D.V.; Nguyen Thi, H.P.; Truong, T.N.; La, D.D. Effective removal of Pb (II) from aqueous media by a new design of Cu-Mg binary ferrite. ACS Omega 2020, 5, 7298-7306. [CrossRef] [PubMed]

34. Makreski, P.; Jovanovski, G. Minerals from Macedonia IX. Distinction between some rhombohedral carbonates by FT IR spectroscopy. Bull. Chem. Technol. Macedonia 2003, 22, 25-32.

35. Miguel, G.-R.; Juan, H.; Leticia, B.; Joaquin, N.-M.; Mario, E.R.-G. Characterization of calcium carbonate, calcium oxide, and calcium hydroxide as starting point to the improvement of lime for their use in construction. J. Mater. Civ. Eng. 2009, 22, 625-708.

36. Mohadi, R.; Sueb, A.; Anggraini, K.; Lesbani, A. Calcium oxide catalyst base on quail eggshell for biodiesel systhesis from waste palm oil. J. Pure Appl. Chem. Res. 2018, 7, 130-139. [CrossRef]

37. Torit, J.; Phihusut, D. Phosphorus removal from wastewater using eggshell ash. Environ. Sci. Pollut. Res. 2019, 26, 34101-34109. [CrossRef]

38. Krishna, K.C.B.; Niaz, M.E.; Sarker, D.C.; Jansen, T. Phosphorus removal from aqueous solution can be enhance through the calcination of lime sludge. J. Environ. Manag. 2017, 2000, 359-365. [CrossRef]

39. Ronkanen, A.K.; Marttila, H.; Celebi, A.; Klove, B. The role of aluminum and iron in phosphorus removal by treatment peatlands. Ecol. Eng. 2016, 86, 190-201. [CrossRef]

40. Sima, T.V.; Letshwenyo, M.W.; Lebogang, L. Efficiency of waste clinker ash and iron oxide tailings for phosphorus removal from tertiary wastewater: Batch studies. Environ. Technol. Innov. 2018, 11, 49-63. [CrossRef]

41. Jiang, C.; Jia, L.; He, Y.; Zhang, B.; Kirumba, G.; Xie, J. Adsorptive removal of phosphorus from aqueous solution using sponge iron and zeolite. J. Colloid Interface Sci. 2013, 402, 246-252. [CrossRef]

42. Guo, G.; Ekama, G.A.; Wang, Y.; Dai, J.; Biswal, B.K.; Chen, G.; Wu, D. Advances in sulfur conversion associated enhanced biological phosphorus removal in sulfate-rich wastewater treatment: A review. Bioresour. Techol. 2019, 285, 121303. [CrossRef]

43. Loganathan, P.; Vigneswaran, S.; Kandasamy, J.; Bolan, N.S. Removal and recovery of phosphate from water using sorption. Crit. Rev. Environ. Sci. Technol. 2014, 44, 8. [CrossRef]

(C) 2020 by the authors. Licensee MDPI, Basel, Switzerland. This article is an open access article distributed under the terms and conditions of the Creative Commons Attribution (CC BY) license (http://creativecommons.org/licenses/by/4.0/). 